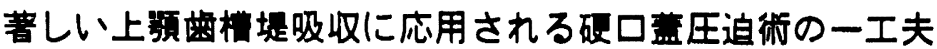

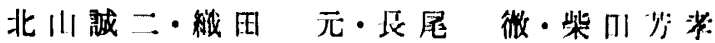

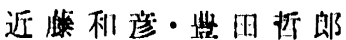

\section{A modification of hard palate compression for marked atrophic maxilla}

\author{
Seiji Kitayama = Hajime Oda - 'Tohru Nagao \\ Yoshitaka Shibata - Kazuhiko Kondou • Tetsurou Toyoda
}

\begin{abstract}
Authors modified the palatal osteotomy of hard palate compression correcting marked atorophic maxilla. This improved method ensured the union of a palatal bone.

The modified hard palate compression, tuberplasty, zygomaticoalveolar crest compression and vestibuloplasty were applied simultaneously for two cases of severe maxillary alveolar atrophy, that had successful results.
\end{abstract}

Key words: hard palate compression, maxillary alveolar atorophy

錯

\section{言}

無歯額の頻堤の著しい吸収に対し補緅前処置として種 種の額堤形成術が行われるようになったが，上䫟は下顎 に比へ頻度は少なく, 上顯では口腔前庭形成術が多く行 われているよらである ${ }^{1 \sim 3)}$. しかし上顎総義歯の維持安 定には種々の要因があり，口蓋が著しく浅い症例では口 腔前庭形成術だけでは義歯の十分な維持安定は望めな い.これに対し頼骨下稜圧迫術 ${ }^{4}$ ， 上影結節形成術 ${ }^{5}$ 等 が併用されている。こうした方法でる義歯の前後的な動 摇を著しく改善することは困難である.

1976年 Charest and Goodyer ${ }^{6)}$ は硬口蓋に逆U 型の 骨切りを行い口蓋を深くし義菡の前後的動摇を防ぐ方法 を報告している. 1978年 Leonard and Howe ${ }^{7)}$ を全く 同様の方法を1974年から行っていると報告している.こ

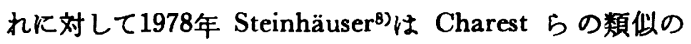
方法は既に1931年 Wassmund ${ }^{93}$ が報告していることを釈 介すると同時に，口蓋正中部に二本の矢状骨切りを加え て，さらに口蓋部を深くする方法を報告している。

名古屋第一赤十字病院菌科口腔外科

（主任：北山誠二部長）

Department of Oral and Maxillo-Facial Surgery,

The Japanese Red Cross Nagoya First Hospital

(Chief: Dr. Seiji Kitayama)

受付日：昭和61年11月25日

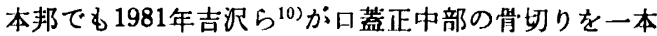
にする変法を報告し，これらの方法を硬口蓋圧迫術と命 名している(図1).

著者らも吉沢一高橋変法を応用したところ，口蓋板が 痹合せず，咬合時義㽤が沈下して安定しない症例が生じ たため，骨切り法に若干の改良を行い良好な結果を得て いるので報告する。

\section{手 術 法}

吉沢一高橋の方法に準して骨口蓋の骨切りを電気エン シシンおよび細いフィッシャーバーを用いて行っても，口

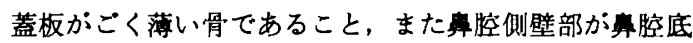
部，即ち骨口蓋部より広いため骨切りを行って口蓋板を 上方に押し上げた場合，口蓋板と上箱骨との接触が不十 分で骨瘺合不全を生ずる場合がある (图 2).

著者らは，こらした点を防ぐ目的で骨切りに若干の工 夫を加えた。

切開および粘膜骨膜弁の剥離：歯槽頂部を一側から対 侧の上䫇結節まで逆U字型に切開し, 硬口蓋部の粘膜骨 膜升を豩離翻転する. その際, 切曾孔の脈管は切断し て，両側の大口蓋孔からの脈管は温存する。

骨切り術：まず切歯孔から正中口蓋程合部に沿って硬 口蓋後縁まで骨切りを行う， 口蓋板の厚さは切歯孔部は $3 \sim 5 \mathrm{~mm}$ あるがその他の部は $1 \sim 2 \mathrm{~mm}$ 前後とごく 薄くなっている。この点を注意してフィッシャーバーで 

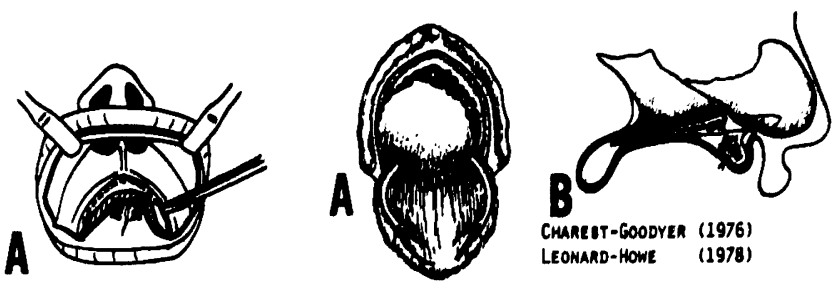

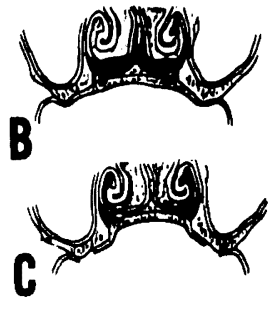

WASSMUNd (1931)

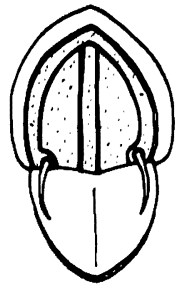

STE INHÄUSER (1978)

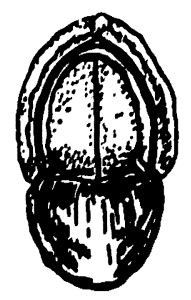

吉沢一高柏 （1981）

图 1 硬口蓝王追㭪

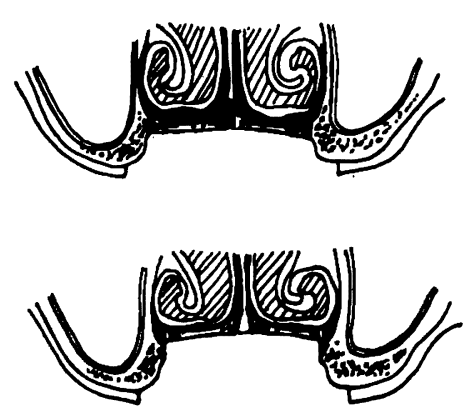

因 2 吉沢一高橋変法に上る硬口蓝骨切り

切崔する，ハーが口蓋板から算中隔部の骨に移行した時 点で手の感蚛から判るのでパーによる切崔を止める.そ の後は薄手のノミで両外側上方に向かって手圧で萛中隔 部の骨との連結を断つ. 次いで口蓋板の周囲の骨切りを 行5. 田雪部は口蓋板と歯槽突起の移行部から骨切りを 始め, 約 $1 \mathrm{~mm}$ 外側の仮想線に向かって, すなわち上外 側に向かい口蓋板とは約60度の角度でハーを用いて切崔 する．前歯部は口蓋板と歯槽突起の移行部の約 $1 \mathrm{~mm}$ 外 側から上内側に向かい，口蓋板とは約45度の角度で骨切 りを行う，最後に脈管神経を保護しなからら大口蓋孔周囲 の骨切りを行う（图3A，B，4）.

口蓋板の举上：骨切りが終了したら，口蓋正中部の骨 切り線から貫中隔が突出するように口蓋板を外上方に押 し上げるが, 後方よりも前方, 外側よりも正中側を大き く移動させ，突出した盘中隔は切除する，上方へ押し上 げられた口蓋板は糞腔側壁および萛中隔との接触面積が 增大し強固な骨癒合が期待できる（図3 C, 4).

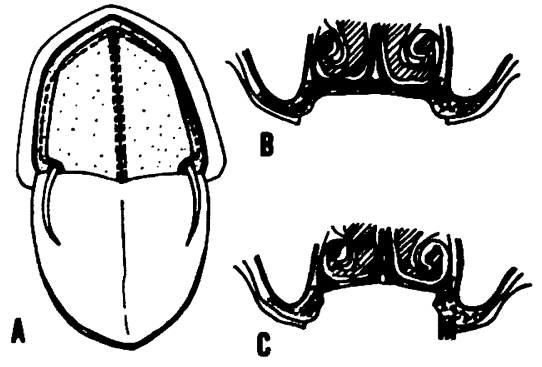

凶3著者らの骨切り法
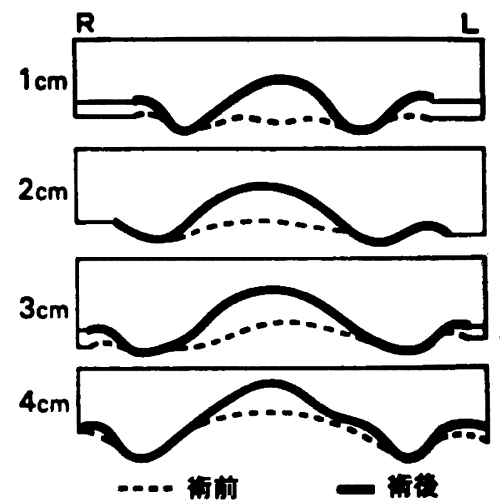

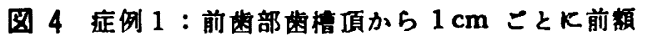
断した模型をトレースし，重れ合わせた。 政前および皃後 6 か月.

阵合：粘䐜骨膜弁を元に戻し䋖合する.

床による圧迫：旧義崡の床縁を延長するか，新たに印 象採得し石声模型上でェルコブレス®を用いて作製した 


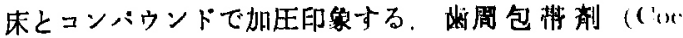

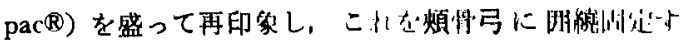
る. 固定は 4 週間行5.

症

例

\section{症例 1}

患 者: 52歳 男性。

初診: 1982年10月ロ日。

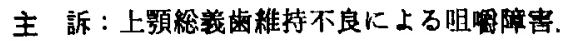

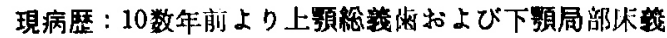
梅を近医で装着したが 1 年前より椎持が悪く、调整を受

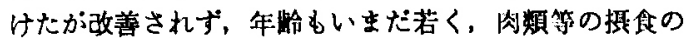
希望が強いため，他医を受影し処盘を受けたが改善がみ られず当科を紹介され来院した。

全身所見：体格，栄巷に中等度，全身状態は良好。

口腔内所見：上頻畨槽突起の吸収か藉しく，口蓋の深 さはほとんどない，口腔前庭る浅くなり，臼部部槽突 起は頼骨下棱近くまで退椎し, 上䫑結節も平坦になって いる．前歯部と上顠結節部に浮動菌肉があり一見すると 雨槽堤の存在を思わせた（写高1 A).

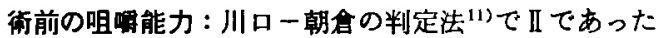
(表 1 ).

x線所見 : 大日雨部の断層写真では歯䏆突起が無くほ

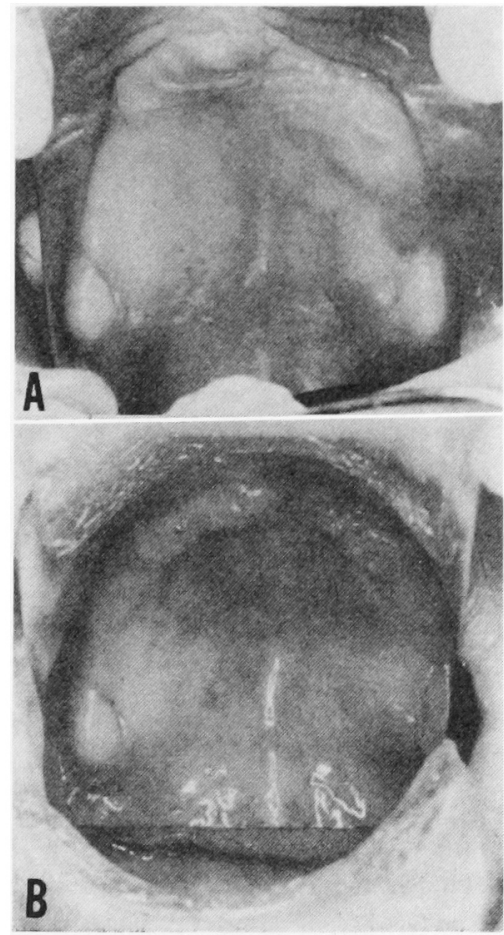

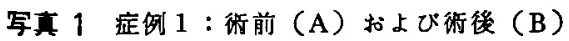

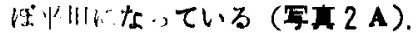

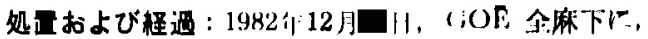

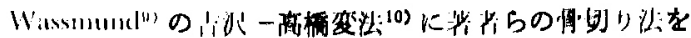

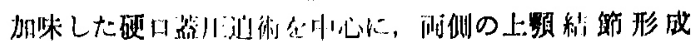

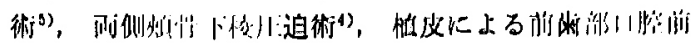

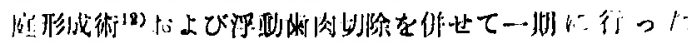

表 1 食品硬度モデル

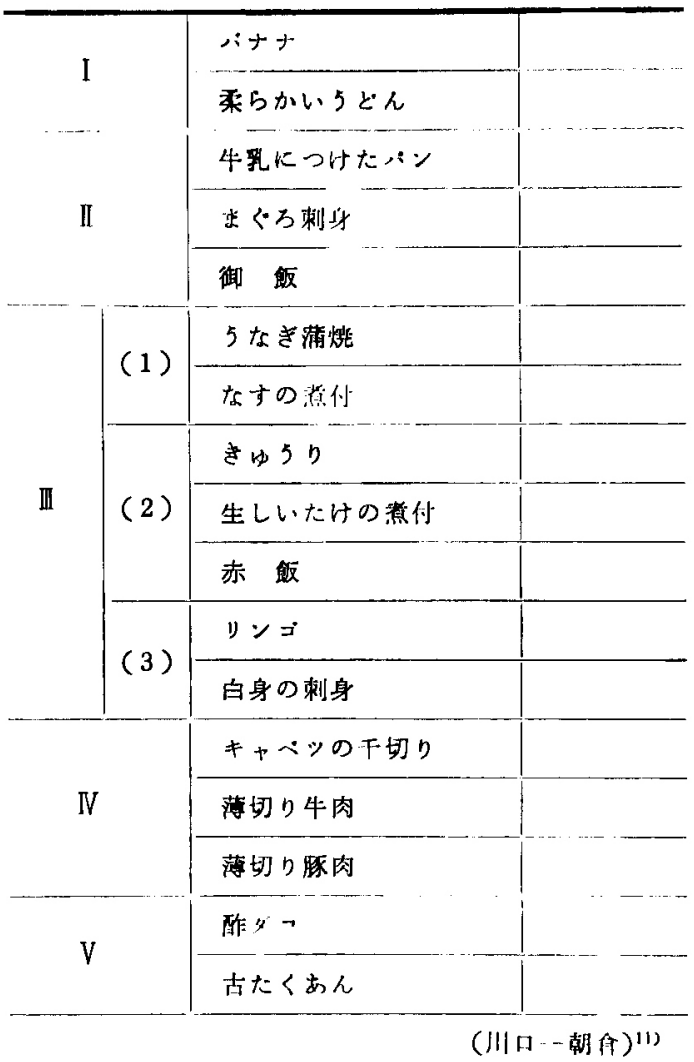

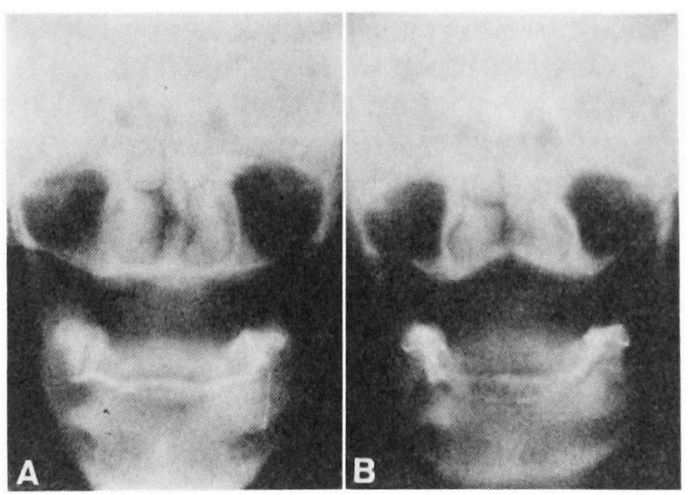

写重 2 症例 1 : 術前断層X線写真 (A) 拉よび術 啳 (B) 


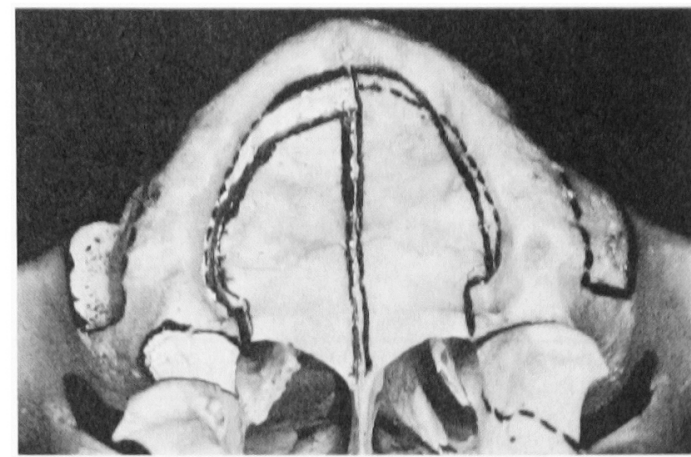

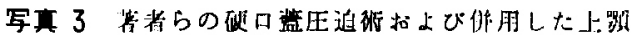

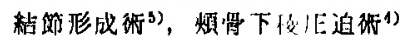
左側は骨切り線を图ぶし，右侧はモデルサ 一シェリーを行っている。

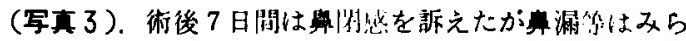
れなかった。術後 1 か月で來を除去した，口盐部は前幽 部で $9 \mathrm{~mm}$ 深くなって扰り，上䫑結節，齿槽堤共に良く 形成されていた。この時点では旧義阰を改床して装着し

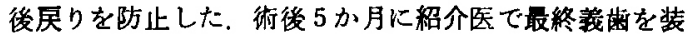
着した。

術後 6 か月の断圈X楾写真であるが，明らかな口蓋の 举上が認められる。また下真が狭くなっているが，自 覚症状はなかった（写直 2 B).

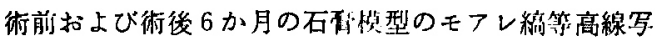

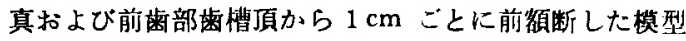
をトレースして重ね合わせたものから，明らかにい蓋や 口腔前庭部が深くなり，上靧結節が良く形成された状態 が伺之る（写直 4 ，图 4)。䄪 4 年余後の現在，前齿部 口腔前庭形成部が $1 \mathrm{~mm}$ 後戻りした他は变化無く義菌の 吸着も良好で，咀絪能力はNまで回復し患者は满足して いる(写真 1 B).

症例 2

患 者: 64歳 女性.

初 診: 1984年 4 月日。.

主 訴：上靧総義菌維持不良による咀哷障害.

既往歴：内科で高血圧症の治療中.

現病歴：44歳時，上顎骨骨䯣炎のための某大学で上顎 骨部分切除を受け，その後局部床義齿を使用していた。

56歳時より総義画を装着したが，前歯部の顎堤がほとん どないため，維持が悪く再三にわたり新製掞よび調整を 受けたが改善されず，転居に際し他の荘科を受診し，当 科を紹介された。

全身所見：体格，栄養中等度で，全身状態は高血圧以 外良好である。

口腔内所見：前歯部は浮動武肉がみられるが顎堤は任 とんどない状態である。目齿部は少し䪽堤がみられる が，上顎結節は平坦になっている（写真 5 A ）。
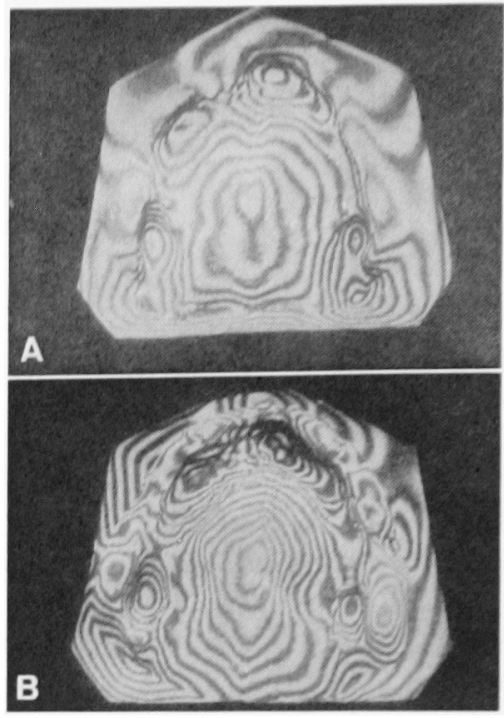

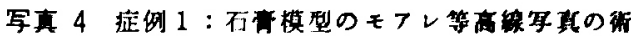
前（A）お上ひ韦後 6 か.月（B）

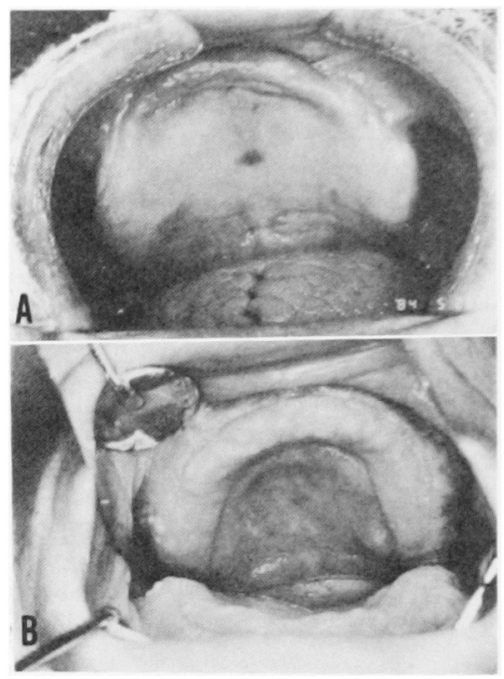

写卉 5 症例 1 ：政前(A) およひ術後 2 年半 (B)

術前の咀嗄能率：川口一朝倉の判定法でII であった。

X楾所見：腐骨等は琶められず，口蓋は平坦になって いる.

処置および経遇：1984 年5月日ＧOE 全床下に硬 口蓋王迫術を中心に，両側上影結節形成術，両側日歯部 粘膜下口腔前庭形成術 ${ }^{13)}$ ，植皮による前歯部口腔前庭形 成術 ${ }^{13)}$ および前梅部浮動歯肉切除を併せて一期に行っ た。 1 か月後，床を除去し旧義歯をりベースして装着し た. 術後 1 か月に紹介医で義齿を新製した。

術後 2 年 6 か月の現在，義歯の稚持安定は良好で，勗 


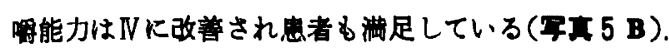

\section{考漂}

上額是の吸収は下類のそれに比べて少なく $1 / 4$ 程度て あるといわれている。したかっって䯪堤形成の频度は少 ないか，種々の方法およびその組み合わせが報告されて いる.それらの中でも硬口蓋压迫術(Wassmund 19319)), 上頻結節形成術 (Celesnik 1954 ${ }^{\mathrm{s})}$ )，㮌愲下棱压迫術 (Heiss 1954`) は上額特有の方法である。特に硬口真压

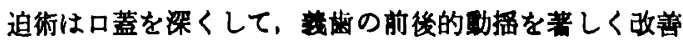
する特徽を有している8,7,9)。この行式は 1931 年 Wass-

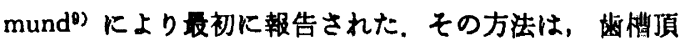
に切開線を入れて，粘膜骨膜弁を梨状孔まで制離し，そ

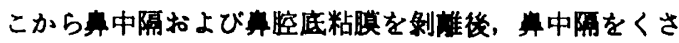
び状に切離する，次いで口蓋周辺の骨切りを行らため に，その部の粘膜を制離するが中央部は口蓋板への血行 路として温存している。この論文はドイッ語で辢れた ためか，あまり知られないで経過したよらである，その 後の報告は，口蓋粘膜骨膜弁を全層にわたって剝離し， 良い術野で口蓋骨切りを行らため血行路を鼻粘膜に負つ ている. Charest 50) (1956) および Leonard 57) （1958）の方法は，骨切りした口蓋板を蝶つがい、状に下 方に開き，楀中隔をくさび状に切離するためにさらに算 粘膜を一部娳離するので，口蓋板が血行障害に陷る可能 性があるが，Stainhäuser ${ }^{8)}$ (1978）の口蓋正中部に 2 本 の矢状骨切りを行い口蓋を押し上げる方法および吉沢一 高橋 ${ }^{10)}$ (1981) による正中部の骨切りを1本にしたその 変法では，血行路としての宜腔粘膜を損ならことはほと んど無く良好な口蓋の形態が得られる。

その他の本邦での硬口蓋王迫術の報告は少なく，著者

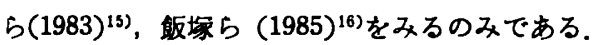

著者らは吉沢一高橋変法 ${ }^{10)}$ を基本にして，骨切り法に 少し工夫を加えて，術後良好な骨窟合を得ている．

術後，旧義齿または床を用いて圧迫固定するが Wass. mund ${ }^{9}$ は $2 \sim 3$ 週間, Leonard $5^{7)}$ は 3〜4 週間, 吉 沢一高橋(10)は 4 週間と述へてており, 著者等も 4 週間行っ た.

口蓋を前四部で強く押し上げることにより義歯の前後 的な動播を防ぐことができる，また正中部を押し上げる ことにより理想的な口蓋の形態が得られるとともに義菌 の左右的な動播を防ぐことができる.

反面, これによって下算道が㹟くなるが，術後何らか の障害がみられたといら報告は無く，Wassmund ${ }^{9)}$ は 老人は粘膜や筋が萎縮して鼻腔が広大であるので，系腔 が狭くなってもさほと影警がない，さらに鼻呼吸の気流 は注とんど中具道を通るため阻害されないことを指摘し ている。著者らの経験でも，症例 1 は52歳と比較的若か ったが， 2 例とも術後 1 週間はと浮腫による算閉がみら
れたが，その後は何ら塆踷をみていない，

觔の零引が無いとい5特微も有り，再発の根告はみら

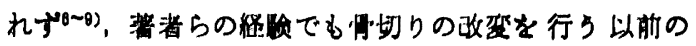

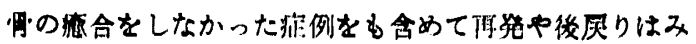
られなかった。

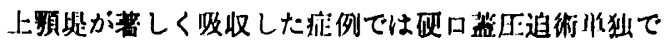

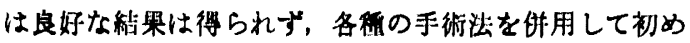
て理想的な影坺が形成される，Leonard らつは粘䀧下口 隆前庭形成術を同時に行ったが良好な結果が得られす， 以後はその他の術式は 3 週䦌勭に清ませると述へてい

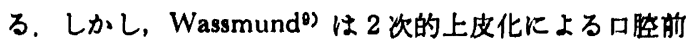
庭形成術, Steinhäuser $\left.{ }^{9}\right)$ (遊倠粘瞙移植による口腔前庭 形成術，吉沢 ${ }^{(0)}$ ( 2 㛲骨下稜压迫術，粘膜下口腔前庭形 成術，浮動齿肉切除術を同時に行い良好な結果を得てい， ろ. 著者らも上顎結節形成術, 植皮に上る前菡部口腔前 庭形成術, 浮動齿肉切除を同時使用し, さらに症例 1 で は頓骨下稜圧迫術, 症例 2 では日齿部粘膜下口腔前庭形 成術を併せ行い良好な結果を得ており，特に口蓋王迫術 と他の額堤形成術を分けて行ら必要性はないと考えてい る.

著者らは，硬口蓋圧迫術を中心に上額結節形成術, 頓 骨下稜圧迫術に口腔前庭形成術を行った场合には，全上 䝷堤形成術と称したいと考えている.

従来, 咀婙能力の評価に用いられた石原 ${ }^{17)}$ の篩分法 は，同一のものをどれだけの割合で細かくできるかで評 価する方法である。

川ロ一朝合 ${ }^{11}$ は，実際の食品を基渋にして患者か， “何が食べられるか”“何が食べられる様になったか”評 価できる方法を報告している。この方法は简便で，臨床 に即しており，患者に対して説得力のある優れた方法で ある.

\section{結語}

1）上顥堤が著しく吸収し口蓋が平坦になった症例に 有効な Wassmund の硬口蓋圧迫術の吉沢一高橋変法に 対し，著者らは骨の哌合を確実にするために骨切り法の 改変を行った。

2 ）改変した硬口蓋圧迫術を中心に上額結節形成術, 頓骨下棱圧迫術, 口腔前庭形成術, 浮動齿肉切除術等を 同時に併せ行った 2 症例に良好な結果を得たので報告し た.

稿を終わるにあたりこ校閲いただいた爱知学院大学第 2 口腔外科学教室河合 幹教授に深懒いたします。

本論文の要旨は, 第26回日本口腔科学会中部地方会 (1983年11月19日）および第 11 回日本口腔外科学会中部 地方会（1986年 6 月 8 日）飞打いて発表した。 


\section{引用文 塥}

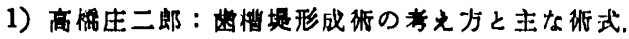
日海医師会婄 27：463-470 1974.

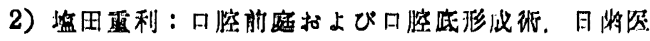
阤全被 29: 2-9 1976.

3）国山界：地を安定させるための外科的処作。

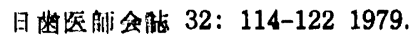

4) Heiss, J.: Die chirurgische Gestaltung des tragfahigen alveolarfortsatzes. In Die prothetische Versorgund des zahnlosen Mundes. ZahnMund-und Kieferheilkunde in Vortregen 14: 961954.

5) Celesnik, F.: La plastique des tuberosites dans les cas d'atorophie du maxillaire superieur. Arch Stomat 9: 82-93 1954.

6) Charest, A. and Goodyer, D.: Palatal osteotomy: a simple approach to maxillary alveolar atrophy. J Oral Surg 34: 442-444 1976.

7) Leonard, M. and Howe, G.L.: Palatal vault osteotomy. Oral Surg 46: 344-348 1978.

8) Steinhäuser, E.W.: Methoden zur operativen Verbesserung der GaumenWolbung. Zahnarztl Prax. 29: 50-54 1978.

9) Wassmund, M.: Uber chirurgische formgestart- -ung des atrophischen Kiefers zum zwecke protetischer versorgung. Vierteljahrsschr Zahnheilk 47: 305-319 1931.

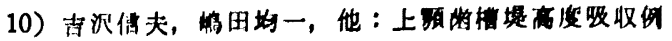

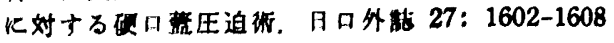
1981.

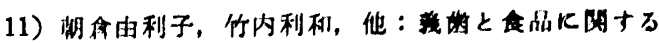

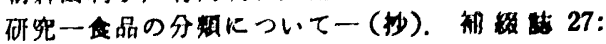
4171983.

12) Pichler, H.: Zur Behandlung bosartieger Oberkiefergeschwurste. Arch Klin Chir 167: 7697751931.

13) Obwegeser, H.L.: Die submukose Veatibulumplastik. Dtsch Zahnaerztl 14: 629-639 1959.

14) Tallgren, A.: The continuing reduction of the residual alveolar ridges in complete denture wearers: A mixed-longitudinal study covering 25 years. J prosthet Den 27: 120-132 1972.

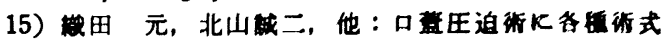

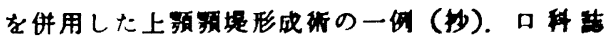
34: 2541985.

16）飯塚忠彦，楠本建司，他：硕口等王迫化化と中

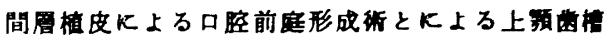
堤改善手吏について(拘). 口科詰 33: 7741984.

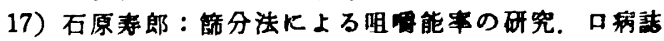
22: 207-255 1955. 